\title{
Strategic Priorities for Interaction Between TNC's and Russian Retailers in the Context of Global Economy Digitalization
}

\author{
Larisa Egorova \\ Department of World Economics \\ Kuban State University \\ E-mail: 1-egorova-@mail.ru \\ Ekaterina Egorova \\ Department of World Economics \\ Kuban State University \\ E-mail: Katie-egorov@mail.ru
}

\author{
Tatiana Logvinenko \\ Department of World Economics \\ Kuban State University \\ E-mail: Tatian.logvinenko89@gmail.com \\ Temur Sulejmanovich Aliev \\ Department of World Economics \\ Kuban State University \\ E-mail: aliev686@gmail.com
}

\begin{abstract}
The new step in the global Industrial Revolution 4.0 consists in the widespread implementation of digital technologies in the leading sectors of national economies and world economy in general. It is fully referred to the external trade sector when transformation of the Russian retailers, interacting with transnational corporations (TNC), into digital enterprises meets modern requirements of the world economy.
\end{abstract}

Keywords - digital transformation; digital economy (DE); industrial revolution; digital system; comparative analysis of government programs for transforming the digital economy; Russian retailers; transnational corporations (TNC); external trade interaction

\section{INTRODUCTION}

Digital transformation in economy may lead to the new stage of fierce competition among governments for gaining the advantages in the world economy. Therefore, strategies and development programs of digital economy (DE), creating favorable conditions for the development of external trade interactions of the companies, are in the spotlight of state leaders and scientific community as well. A comparative country analysis of the state programs development for the transformation of the digital economy as the basis for development of external trade interactions between TNC of the EU, USA, Singapore, China and Russia, enabled to identify the key areas of digital transformation of the world economy.

II. DigitAL TRANSFORMATION OF ECONOMY AS THE BASIS FOR DEVELOPING THE EXTERNAL TRADE

INTERACTION BETWEEN CORPORATIONS: INTERNATIONAL ASPECT

For a long time in civilization, there was a request for sustainable development, which is confirmed by the Club of
Rome documents, Sustainable Development Goals (SDG) from the UN, etc.

In order to address the issues of sustainable development, the international community, business and states must be politically, economically , socially technologically, legislatively, ethically, morally, ecologically and in some other ways interrelated [1].

However, scientific approaches used nowadays in the study of development peculiarities of external trade interaction between corporations do not address multiplicity of aspects. Currently it is digitalization that is able to interconnect all the elements of interaction between economic entities of different countries into a single system ("Fig. 1")

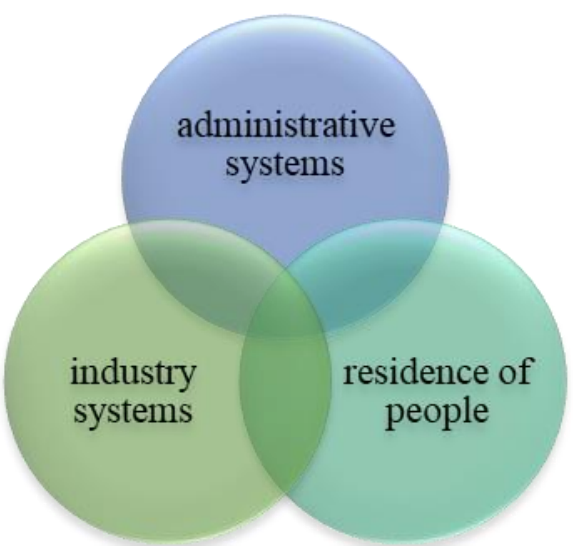

Fig. 1. Elements of the digital system.

Digital systems in the country aspect include: administrative-territorial systems (i.e. municipalities, districts, regions, countries); sectorial systems (i.e. enterprises, business ecosystems, industries); densely 
At the same time, digital transformation in economy may objectively lead to the new stage of fierce competition among governments for gaining the advantages in the world economy. Therefore, DE strategies and development programs are in the spotlight of state leaders and scientific community as well. In this regard, we will analyze the experience of developing DE strategies and programs with a high use of digitalization in economy ("Fig. 2").

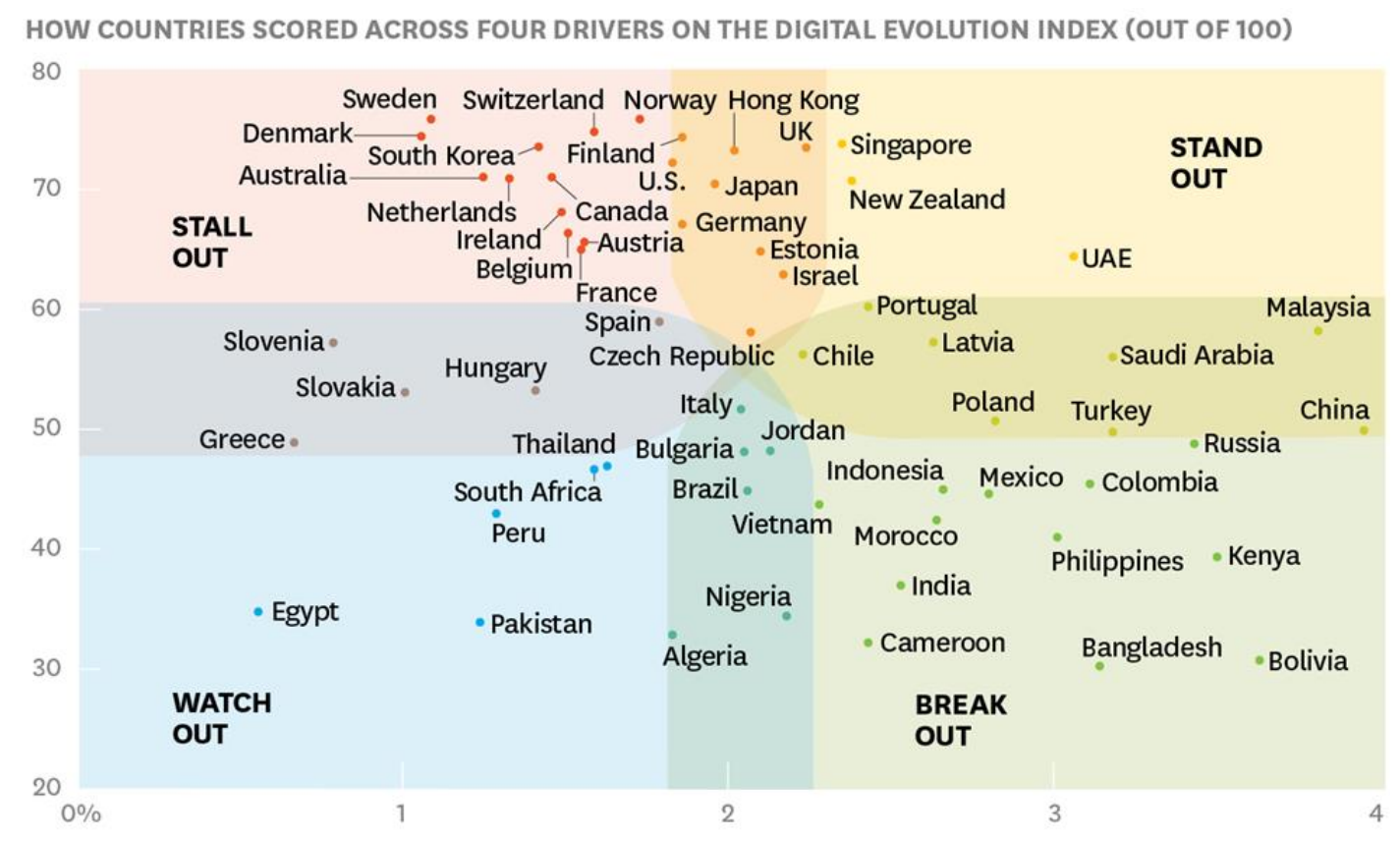

Fig. 2. The digital evolution index, 2017 [9].

It is believed that Singapore and the USA are the leading countries in the digitalization of economy. The governments of these countries have a proactive position in introduction of the digital technologies. Moreover, as we see it, it deserves attention to study the experience of Great Britain, the government of which published the DE development strategy with clearly defined goals and tools for their achievement, and of China, which seeks to use DE in order to dominate in the world economy. Understanding the experience of other countries enables us to determine possible competitive advantages for Russia to map out the external trade strategy of national corporations in order to strengthen their position in the world market.

\section{THE MAIN APPROACHES TO THE FORMATION OF THE DiGITAL ECONOMY IN THE UK}

The goal of the UK digital economy development strategy is the world leadership in building a cyberspace that provides the national prosperity through productivity growth, creation of highly skilled and highly paid jobs in the future and that enables citizens to live safely and work online [3].

The implementation of this goal supposes solving the problem of proportional (no crisis) development of the economy. The ground for the UK's ambitious program is the fact that it is the leader in world finance, has competitive a. on the horizontal axis - the speed of digital transformation; on the vertical axis - the level of digitalization advantages in artificial intelligence (AI) sphere used by business and final consumers and in the FinTech sphere as well, which consists of the companies using IT in the financial service market provided mainly through the Internet.

Drawing on the given example, it can be assumed that introduction of such a DE model focused on redistribution processes can lead to a number of negative aspects. For instance, the emergence of non-government robotic community where the expected growing role of AI will result in coalescence of intellectual and financial elites, growth in mass unemployment with the degradation of those who use DE achievements, getting basic income.

On the other hand, objectively, the use of the DE model has many positive effects: establishing a world-class digital infrastructure; involving the international business and community into the DE space; creating a free digital skills training system for all the interested with public investments to universities which make researches in the field of robotics and AI; improving the quality of service for citizens in the Internet (E-Government); providing cyberspace security, etc. 
financial multinational enterprise (MNE). According to the Global Innovation Index 2016 (GII), Singapore is the sixth largest innovation economy in the world.

The country pays attention to cyber security and data confidentiality. There is its own SNSP (Smart Nation Sensor Platform) for collecting, analyzing and exchanging data between economic agents, which, according to the Government, should contribute to decisions aimed at improving the quality of life. There is also Smart Nation and Digital Government Group (SNDGG), which is responsible for coordinating government agencies' actions, industry and society to apply digital technologies and innovations to improve the citizens' quality of life.

\section{THE MAIN APPROACHES TO THE Formation OF THE DiGITAL ECONOMY IN CHINA}

- free and open Internet to expand international trade and minimization of the governmental barriers that set strict rules of localization for cyber security;

- trust and security on the Internet, including the protection of intellectual property;

- Internet accessibility by eliminating uneven Internet coverage in the country and providing quick Internet access with minimal barriers for data and service flow, teaching digitalized world economy to American workers;

- innovations and new technologies in DE, which create new opportunities in international commerce and allow solving many long-term political issues.

In order to implement the directions of the Digital Economy Agenda the Department of Commerce, in the collaboration with the US State Department, has launched a pilot program "Digital Attache", which is designed to support US enterprises with the help of American global ecommerce channels to increase high-tech export of their products.

\section{THE MAIN APPROACHES TO THE DigitAl ECONOMY IN SINGAPORE}

According to Singapore Government "the country seeks to become a smart nation to maintain a better life, strengthen the communities and create more opportunities for everyone". Being "smart" means not only introduction of complex technologies but also their use by the society to solve its problems [5].

"Ultimately, our vision of "smart nation" is citizens, not technologies". In Singapore, five key domains have been identified by the Government in which digital technology can have a significant impact: transport, environment, business productivity, health and public sector services.

The Government sees its role in creating the infrastructure for developing and implementing of digital technologies as well as in pursuing a policy of encouraging innovation, $\mathrm{R} \& \mathrm{D}$ funding ( $\$ 19$ billion as another tranche) and risk insurance. The accelerated DE development can be facilitated by the significant presence of venture capital and
In China, the IT sector is seen as one of the main tools to increase the effectiveness of society economic development.

In order to overcome the negative trends in economy development the Chinese leadership made a ten-year plan aimed at reindustrialization of the country ("Made in China" 2025, which should help China become the world power in DE development with a full cycle of industrial production from fundamental research to mass production of its own innovative goods)

The country already has great achievements in the information and communication industry, in the production of electronic computer technology for aerospace industry and IT medicine. According to the Chinese leadership, at the beginning of 2017 the country took the second place by the level and scale of DE development in terms of its share in GDP production (about 14\%) [6].

China has its own analogies of the largest American IT companies as well as its own innovative companies, especially in the sphere of telecommunications and consumer electronics, such as Huawei and Lenovo. The problem is that these companies are engaged in improving the production technologies but not in revolutionary innovations. All in all the development of the national IT industry is spontaneous, rather than according to the general development plan of China.

Special attention within DE development is paid to formation of the Internet Economy, which is seen as the savior of the economy. According to 2017 data, China has a high share of e-commerce (trade through online stores) $8,4 \%$ of the total retail turnover. Higher rates are only in the $\mathrm{UK}(11,4 \%)$ and Germany(10,2\%). [6]

The modern strategy of China-2049 is to transform the country from the world factory into the planetary laboratory by increasing the IQ level of population. To gain this goal it is planned to intensify informatization, primarily in three key spheres - industry, finance and trade, which, according to analysts, will have contributed Internet economy in the country's GDP up to $10-16 \%$ and labour productivity growth in the sectors mentioned above up to $25 \%$ by 2025 . In 
In Russian economy, transnational corporations are general, due to DE China's GDP growth is predicted to reach $\$ 2.3$ trillion.

\section{THE MAIN APPROACHES TO THE DIGITAL ECONOMY IN RUSSIA AS A BASE FOR DEVELOPMENT OF INTERACTION BETWEEN TNCS AND RUSSIAN RETAILERS}

Nowadays, two projects of the digital economy development are presented and discussed by the expert community in Russia - Program Center and Program Ministry of Communications. [7]

In these programs, DE is defined as "an economic structure characterized by a transition to a qualitatively new level of ICT usage in all the spheres of socio-economic activity".

By state regulation, the authors of the programs mean the creation of a favorable legal regime for introduction and development of IT, access to data and its processing, economic activity and labor relations connected with DE. However, objectively, such goals require developing a scientifically based economic-mathematical model (EMM) which describes this interaction, prevents administrative imposition of numerous duplicate data on enterprises that deliberately reduces the efficiency of economy administration both at the business level and at the country level.

As for such sectors of the Programs as information infrastructure, research and developments, personnel and education, information security, public administration, "smart city", digital healthcare, etc. - the authors here suppose creating conditions for all the citizens to access the Internet, but at the same time, they are presented superficially. The Program almost does not address the problems of creating the digital infrastructure for the development of external trade sector of the Russian economy and expanding of the interaction between Russian corporations and foreign TNCs.

The authors analyzed the state and problems of digitalization of the Russian economy in terms of creating favorable conditions for development of interaction between TNCs and Russian retailers.

Nowadays in the Russian Federation there are 80 out of 100 largest international TNCs, which proves a significant openness of the economy and market, indicates the increase of investment rating and world status, the formation of institutional and competitive environment common to different forms of external trade activity.

Positioning and operating of transnational corporations on the Russian consumer market contributes to expansion of its borders, volume and capacity.

At present the largest transnational corporations apply global strategies in their activity and place the companies in the regions with competitive advantages, which enable to implement cost-effective and large-scale projects due to the brand new technologies, reliable financial support, corporate management practices. represented in 14 sectors: the electrical and electronic industry, the services and trade sector, pharmaceuticals, the food and beverage industry, the automotive industry, chemistry, oil and gas sector.

Most of the TNCs began to explore the Russian Federation market by creating the conditions for marketing their products through investing to advertising campaigns, distribution networks, systems of after-sale service, etc. Transnational corporations are represented in 14 sectors; they are the most successful in the electrical and electronic industry, chemistry, oil and gas sector, pharmaceuticals, the automotive industry, the food and beverage industry, the services and trade sector, etc. In terms of FDI to the Russian economy, the US capital takes the leading place and American transnational corporations are involved into 11 out of 14 spheres. They are mostly represented in electrical and electronic industry. Japanese TNCs showed their best in electrical and electronic industry as well as in the services and trade sector.

The majority of transnational corporations are involved into two interrelated areas - electrical and electronic. These are the transnational corporations which have headquarters in 8 home countries - they are the world famous IBM, AT amp, Motorola, GTE, General Electric, Digital Equipment, ITT, Hewlett-Packard (USA); Sharp Corp, NEC, Sony (Japan); ABB-Asia Brown Bovery Ltd (Switzerland-Sweden); Alcatel, Alstom, Thomson (France); Philips Electronics (Netherlands); Electrolux (Sweden); Cable and Wireless (UK), Siemens (Germany).

A number of largest transnational corporations are eager to establish cooperation with Russian software companies. At present the huge Russian telecommunications market has little attraction to the large companies of this type of business Thus, one of the most famous cellular networks in Russia "Beeline" was formed with the participation of not-sofamous family owned American company «F.G.I. Wireless».

The regulation of the activity of the foreign TNCs in the Russian Federation can be described by many aspects of the current regulatory and legal base of such areas as investments regulation, tax, customs as well as government regulations of mergers and acquisitions and antitrust laws. The greatest importance belongs to the system of regulatory and legal acts in the field of investment regulations, i.e. the regulation of foreign investments.

To regulate the interaction between TNCs and Russian retailers, bilateral investment agreements are used, which are aimed at encouraging direct foreign investments by establishing the rules that improve investment climate and thus create conditions for attracting foreign TNCs. 


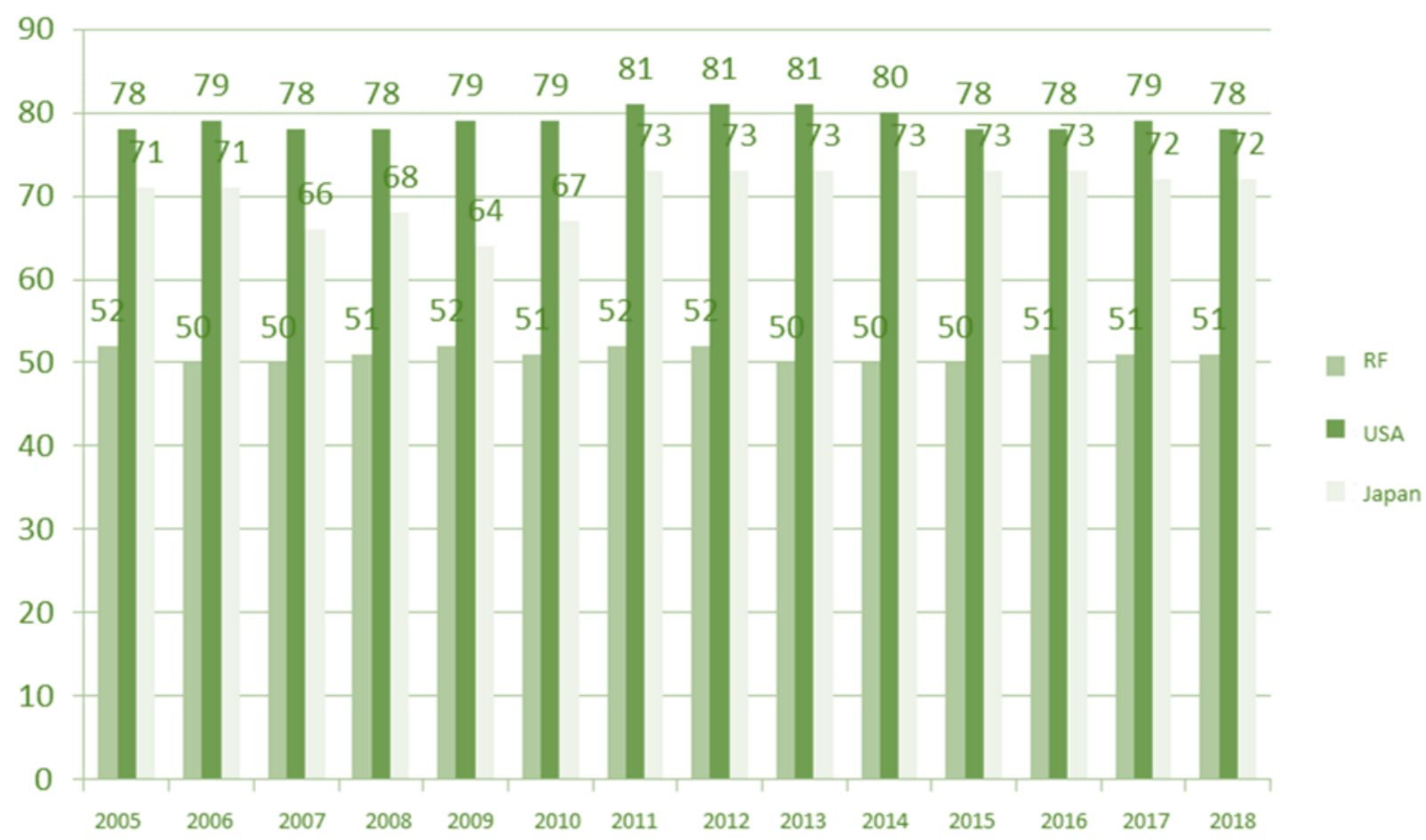

Fig. 3. Index of economic freedom of the Russian Federation, the USA, Japan, 2005-2018 [7].

The level of interaction activity between foreign TNCs and Russian companies can be analyzed by the indicator the index of economic freedom ("Fig. 3"). The conducted comparison of this indicator in Russia, Japan and the USA, which are considered to be the states with a more dynamic development of TNCs, reflects an interesting dynamics. In economically developed countries, there is a tendency to decrease this indicator, which can be connected with the usage of more stringent regulatory methods of financial and real sectors of national economies. In addition, the gap in the value of indicators between Russia and the compared countries is significant, which indicates a lower competitiveness of Russia.

The analysis on the prospects for the development of interaction between the Russian corporations and TNCs showed a positive dynamics and in the future, it is likely to consist in accelerating the pace of business internalization and consolidation of the leading sectors in the world economy.

The main target for protecting Russian consumer market may become an increase in the products supply of a higher level of processing, technologically and technically sophisticated products, the conditions for which can be provided by digitalization of economy. It may involve implementation and development of a system of organizational and economic methods of state foreign economic regulation.

Therefore, there is an urgent need to change the government's approach to implementation of the DE Programs. Today it is impossible not to take into account the experience of foreign countries in its development, not to determine the competitive advantages of national DE (including possible) and specific DE directions (strategy of the world expansion or sovereignty, etc.). Moreover, it is impossible to substantiate the author's targets (Program Ministry of Communications) by 2025 - 10 digital platforms, 10 new training grounds, $50 \%$ of organizations using the information security standards and risk assessment methodology in DE, 50 "smart cities", increase of the average life expectancy to 76 years, etc.

As for the criticism at the authors of Program Center and Program Ministry of Communications, it should be noted that there is no reference to the necessity of the scientifically based EMM, which could effectively develop DE to increase the volume and quality of the national economy.

\section{CONCLUSION}

The comparative country analysis of the development of state programs for the transformation of the digital economy in the EU, USA, Singapore, China and Russia enabled to identify the key directions of digital transformation of the world economy. They are the creation of national digital legislations; digitalization of global industry based on cyber systems, AI, 3D printing in order to increase labor productivity; digitalization of world agriculture (precision farming, digital livestock, agro robots, etc.); big data and 5G connectivity; smart power grids and powerful energy storage devices, including portable; smart cities, digital education and healthcare; transparency and efficiency of public administration; employment growth; cyber security; optimization of tax regulation and investment climate; public funding of breakthrough digital projects ("Fig.4"). 


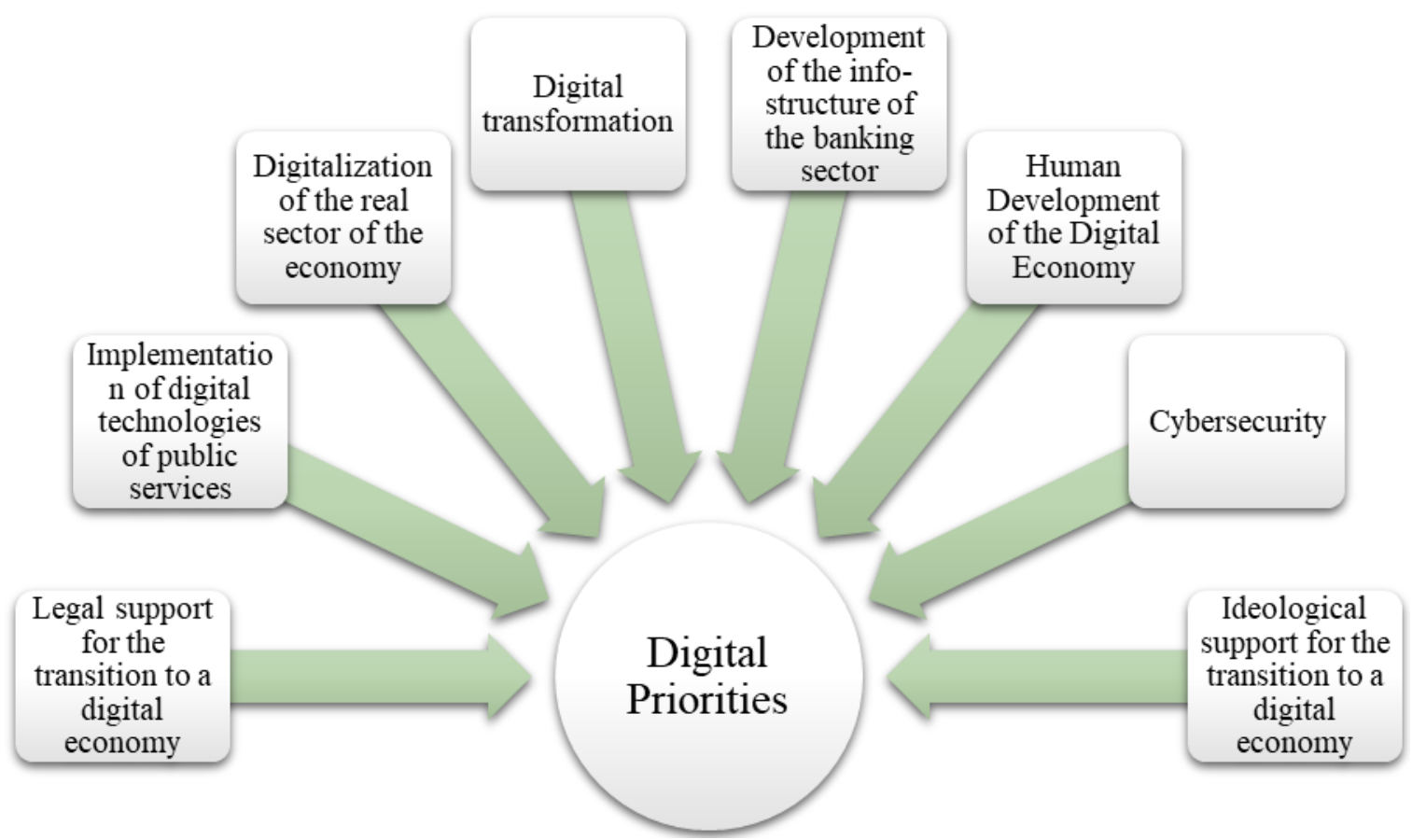

Fig. 4. Strategic priorities in interaction between TNCs and Russian corporations in the conditions of digitalization of the world economy.

Implementation of the priorities in the formation of the global digital economy is possible only on the basis of consolidated efforts of states' governments, representatives of scientific community, members of the world business community and all the citizens of the world to improve the quality of life on our planet. These will require systematic consecutive transformations: digitalization of all the world economy sectors; digital transformation of global information and communication infrastructure; labor force development of the global digital economy; cyber security at the international level.

The development directions of the global economy digital transformation consist in widespread introduction of digital technologies into the leading sectors of national economies and global economy as a whole; transforming the existing traditional enterprises of the real and bank sectors into digital enterprises and banks; determination of the most effective areas of digital transformation of traditional sectors of the world economy sectors; forming a digital development portfolio of country organizations in the ICT sphere aimed at creating the basis for a new stage of the global Industrial Revolution 4.0.

\section{REFERENCES}

[1] S.S. Feshina, O.V. Konovalova, N.G. Sinyavsky INDUSTRY 4.0TRANSITION TO NEW ECONOMIC REALITY. Studies in Systems, Decision and Control. 2019. T. 169. C. 111-120.

[2] P. Delvenne Responsible research and innovation as a travesty of technology assessment? // Journal of Responsible Innovation. 2017. Vol. 4. Iss. 2. P. $278-288$; Est R. van. Responsible Innovation as a source of inspiration for Technology Assessment, and vice versa: the common challenge of responsibility, representation, issue identification, and orientation // Ibid. P. $268-277$
[3] UK Digital Strategy 2017 / Department for Digital, Culture Media \& $\begin{array}{lllll}\text { Sport. } & 1 & \text { March } & 2017 .\end{array}$ https://www.gov.uk/government/publications/uk-digital-strategy/ukdigital-strategy

[4] A. Davidson Commerce Department Digital Economy Agenda 2016/ Department of Commerce, United States of America. May 2016. URL:

https://www.ntia.doc.gov/files/ntia/publications/alan_davidson_digita 1_econ omy_agenda_deba_presensation_051616.pdf.

[5] About Smart Nation // Smart Nation Singapore [Official Site]. URL: https://www.smartnation.sg/about-smartnation.

[6] V. Shultseva Digital Economy of China: "Assimilation! Resistance is futile! "// First Mile. 2015. No 4. URL: http://www.lastmile.su/journal/article/4702 (accessed: July 14, 2017). 20 Katasonov V.Yu. On the digital economy of China URL: http://www.vsesovetnik.ru/archives/22055

[7] A.Efremov Assessing the impact of legal regulation on the development of information technology: foreign experience and Russian approaches to the methodology // Information Law. - 2018. No. 4. - S. 29-32.

[8] World Development Report 2016. Digital Dividends [Электронный pecypc]. URL: http://www.worldbank.org

[9] Final Declaration: G20 States Vow to Promote Global Trade, "Digital Connection" // Sputnik International [Site]. 08.07.2017. URL: https://sputniknews.com/politics/201707081055370421-g20-summitresults-declaration 